\title{
鋼の高温加工强度に゙關する研究 $(\mathrm{I})^{*}$
}

(高温高速度引張り試験装置)

\author{
井上勝郎***
}

STUDIES ON THE HOT-WORKING STRENGTH OF STEEL (I)

(The High Temperature-High Speed Tension Testing Machine)

Synopsis:

Katsuro Inouye

In order to obtain the value of deforming strength of steels at high speed-high temperatures corresponding to such hot-working processes as hot-rolling, forging, extrusion etc., the author specially manufactured a tension-testing machine. Main parts of this machine were as follows:

(1) Deformation speed of specimens at gage length conld be converted into $77 / \mathrm{sec}, 7 / \mathrm{sec}$ $\& 0.8 / \mathrm{sec}$ respectively.

(2) As for the direct resistance heating of specimens using directcurrent, rapid heating was possible within the range of $700^{\circ} \sim 1400^{\circ} \mathrm{C}$. Actual measurements were done standardized by $800^{\circ}, 1000^{\circ 0} \& 1200^{\circ} \mathrm{C}$.

(3) Tension stresss was measured by the use of a capacity-change pick-up and elongation was measured using inductance change. Recording was made by the use of an electromagnetic oscillograph (H-Vibrator).

Using this tension-testing machine, both nominal stress-strain curve and true stress natural strain curve in all deforming conditions of all types of steels were to be obtained, the latter being data of deforming the strength.

In this article, the design and construction of this testing machine, together with a suitable experimental technique were described in details.

\section{I. 緒言}

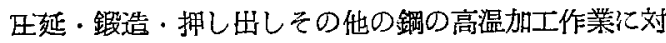
する最も基本的な特性は高温变形热抗であつて我々は作 業の難易, 疪の発生等を之によつて判断し，作業方法の 改善に利用する事が多い，变形抵抗は一般に材料が－椂 な 1 軸引張り又は縮を受けて，变形を生じた時に呈す る応力を以て定義する***，従つてその測定は引張り試 験或いは王縮試験によるのが普通である・所が一方鋼の 高温度に於ける变形抵抗は，材筫，温度，变形速度及び 加工度に藷しく支配される．従つて工業的に有用な变形 抵抗の資料を得る為には，之等 4 条件を実際工嶪に於け る值に合せて器験しなければ無意昧である。例えば， Table 1は継目無し鋼管㱔造に热ける之等の值であるが

* 昭利 29 年 10 月塑性加工専門講㴼会にて発表

** 日本特殊䠒管株式会社

***銅が望性变形を生ずる条件については，周知の様 に多くの吥宽があつて，最終結論に至つていないが，3 軸店力状態に於て

(最大応力) 一 (最小庥力 $)=(1 \cdot 0 \sim 1 \cdot 15) \times(1$ 軸装形抵抗) の時装形を生ずると考えて大きな謓りはない。
Table 1. Temperatures and deforming speeds corresponding to practical rolling

\begin{tabular}{|c|c|c|c|}
\hline $\begin{array}{l}\text { Deforming speed } \\
\text { Temperature }{ }^{\circ} \mathrm{C} \\
\end{array}$ & $100 / \mathrm{s}$ & $10 / \mathrm{s}$ & $1 / \mathrm{s}$ \\
\hline 1200 & $O_{1}$ & $O^{1}$ & $O^{1}$ \\
\hline 1000 & 0 & $\mathrm{O}^{2}$ & $\mathrm{O}^{2}$ \\
\hline 800 & 0 & $\bigcirc^{3}$ & $\mathrm{O}^{3}$ \\
\hline
\end{tabular}

之を見ると,温度については800〜 $1200^{\circ} \mathrm{C}$, 变形速度につ いては $1 / \mathrm{s} \sim 100 / \mathrm{s}$ の範囲で実験を行わなけれぱならな い事がわかる、鋼管製造以外の他の高温加工作業も，特 殊な例を除けば大体此の範囲内に含まれるから，高温変 形抵抗の測定は必然的に高温速度の引張り試験或いは仕 縮試歌となる。之は笑験技術上種々の困難を伴うので, 古来信頼すべき研究はごく少ない，普通のる萇試験機を 用いた高温引張り試験は比較的実行容易であるから，発 表例もいくつかあるが，此の場合の变形速度は $10^{-3} / \mathrm{s}$ 〜 $10^{-1} / \mathrm{s}$ であるから, 变形抵抗の測定值としては不十 
分である。

寒者は日常継目無し鋼管の製造に従事する閒に，鋼管 用の各種鋼材の高温变形抵抗の正確な值を知る必要に度 々遭遇したが，上記の様な理由から，渶足な資料を得る 事かできなかつたそこで之等を中心とした信頼すべき 測定值を得たいと考え，数年前より笑験を行つていたぶ 最近一通り実験を完了したので，としにその結果を報告 する・

\section{II. 試験方法の検討}

高速压縮による高温变形抵抗の測定は，円筒形試験片 そ落下重錘で王縮し，その際の落下エネルギーAと， 压縮前後の試片の高さ $h_{0}$ 及び $h_{1}$ 方ら，次式により平 均变形抵抗 $k_{1}$ を計算する・但し $V$ 仙試片の容積であ 2.

$$
A=k_{f} \cdot \boldsymbol{V} \cdot \ln h_{0} / h_{1}
$$

この方法は比較的容易に行えるが，次の欠点がある。

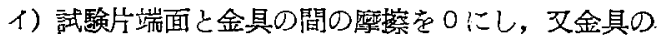

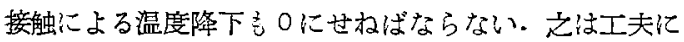
より或る程度沦は達せらえるが，完全は期し難い。

ஈ）王縮变形の特質として，变形速度は○より始まり 最大値迄上算し，再び0迄低下する．往つて（1）式で 求わた $k_{f}$ は变形速度に関して或る平均值となり，一定 变形速度儿対する值は得られない。

八）王縮力き直接測定する事が困難であつて，応力・ 歪曲線加得られない，徉つて（1）式から求めた $k_{f}$ 法加 工度についても平均值である。

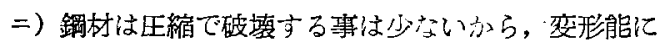
関する情秛力゙得難い

この方法による高温变形抵杭の研究は Hennecke ${ }^{2}$ 及 び池島 ${ }^{3}$ がある－殊に池島の研究は種々の工夫によつて 上記諸欠点の影響を少くした貴重な斫究であるが，しか し本質的には之等の欠点法避け難いるのである.

高速引張りによる試験には上記の欠点がなく，一定变 形速度に於ける応力・歪曲線を得る事ができる．之は变 形担抗の測定として最も望ましい点である. 又同時に变 形能関する情報も得られる便宜がある，区面最大の久 点沈，伸び率 $20 \%$ 程度で局部収槯を生ずる為に，之以 上の加工度に対する值を求め難い事である，此の方法に

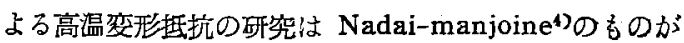
ある.との研究は $10^{3} / \mathrm{sec}$ の变形速度迄含み，著名な そのであるが，湘定鋼種が少なく，又結果の検討が工業 的見地からは不十分と思われる。

筆者は上記諸点を比較検討した上で，引張り試験法に
よつて変形䞰抗を测定する事にしだ

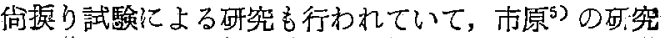
は此の例であるが，挥りによる試片内の応力分布は不均 一であるから，相対的な比曾はできるが，变形抵抗の絶 対值は求め難いので採用できない，又王超機のロール压 力の测定から実際作業に於ける变形抵抗を求める研究も 数多〈行われていて, Siebel ${ }^{6}$, Pomp ${ }^{7}$, 豊島息等力些 の例であるが，之等の值は実用上貴重ではあるが，純粋 变形抵抗の測定值としては，纴延变形に於ける各種損失 の程度が不盺であるから，完全なものとは言えない。

\section{II. 試験装置の概略}

今回の斫究の為に，䈉者は新たに高温高速度引㙊り試

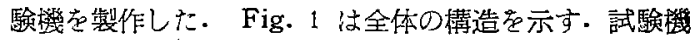

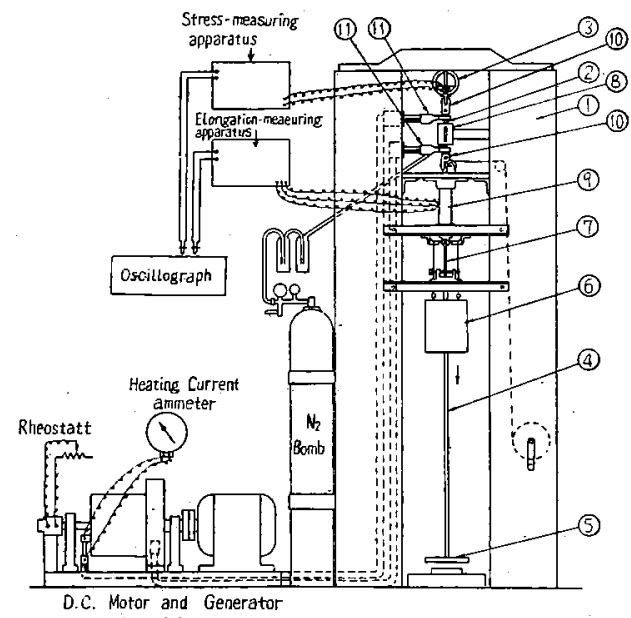

Fig. 1 High temperasure and High speed tension testing mackine.

本体(1)は厚鋼板の愹接で作つた碳丈な架構である・試驗 片は(2)であつて，その周团を酸化防止用ヶース(8)でかて み, ボンべからの $\mathrm{N}_{2}$ ガスを流してある. 試験片の上端 は荷重测定装置(亿連結し，下端には長い荷重用ロッド (4)が吊り下げてある・等の連結部は可觀接手(10)により ビン・ジョィントにしてある・ロッド(4)の下端は荷重受 け且(5)になつていて，予め吊り上げておいた落下荷重(6) がクラッチ(7)を外すと自由落下してきてとにあたり，蔀 婑荷重を試驗片に后える、試験片の伸びの測定は，伸び によるロッド(4)の移動をインダクション・コイル(9)によ

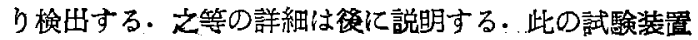
の全体の高さは $2 \cdot 5 \mathrm{~m}$, 落下荷重の品上げ高さは約 $1 \cdot 15$ $\mathrm{m}$, 荷重は $30 \mathrm{~kg}$ である。 
試験片の加蓺は直流を試験片に直接流して，その抵抗 熱による.その為の直流は尃用の直流発電機を围い，之 から太いリードによりターミナル(11)電流を尊く・ター ミナルは試験片の雨端にボルト止めしてある．高速度变 形はこの様に落下荷重で得られるが，中速度及び低速度 变形には無理である。この埸合は試験機自体はそのまま にしておいて，荷重装置だけをとりかえた。それは７馬力 のギャード・モーターを更にブレーで適当に減速した回 転檕によつて, 試験片下端に垂らしたローラー・チェン を港取る方法である.中速度と低速度の切り換えは，プ レーの取り換えによつて行なう。

\section{IV. 試験片加熱法}

試験片の加熱は，6V， 500A 程度の直流を試験片に 直接流して，抵抗熱により加熱する方法をとつたとの 様な場合に普通行われている方法は，別の加熱少内で試 験片を加熱しておき，之を手早く取り出して試験機にと りつけるのであるが，之に比べて䈐流加熱法は次の椂な 特長がある。

1）高温迄梗く短時間で均一に加熱できるので，酸化 防止が容易であり, 又如何なる高温度の加熱も可能であ る.

口）加熱終了と同時に荷重なかける事ができるから， 加熱炍法の如く师出しから試験迄に生ずる温度低下や酸 化の心酩か不要である.

筆者が用いた加熱篭源は $7 \mathrm{KW}$ の直流発笔機であつ て, 压磁モーターの可変抵抗の調節により試験片に流れ る電流を加隇して，加熱温度を自由に变化できる。

ての加熱法で， $800^{\circ} \sim 1200^{\circ} \mathrm{C}$ の加熱温度迄の熱時 間は 2 分間とし，保持持間は 3〜 5 分とした。温度を均 一にする為には之で十分である。

試験片の凰囲は鋼管のケースでかてみ，その中に $\mathrm{N}_{2}$ ガスをオーバー・フトーさせて酸化防止を行つた・之は 光高温計で温度を测定する便管の為である. $\mathrm{N}_{2}$ ガスは 純造 99・7\% 程度の市販晶を用いたが，ての目的には十 分であつて，試験終了後生じている酸化荧の厚さは最大 0・01 mmである.

$\mathrm{N}_{2}$ ガス中で短時間ではあるが高愠に加熱するので，

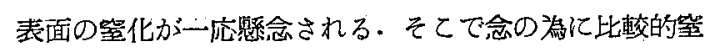
化し易いと思われる低宸素キルド鎉，5\% Cr-0.5\% Mo 銅及び $3 \% \mathrm{Al}$ 鋼を, $800^{\circ} \mathrm{C}$ 及び $1200^{\circ} \mathrm{C}$ 亿規定の加 熱を行い，加蓺前後の表面層の $\mathrm{N}_{2}$ の分析を試みた，乙 の結果, $\mathrm{N}_{2}$ 量の変仕は測定变舫の钴国内にあり, 問題 とするに足りない事がかかつだ.

\section{V. 試験片形状}

引張り試験にあつては円形断面の試験片か試験皘度上 及び工作上便宜な事は当然であり, その直径の寸洗は試 験機の容量から容易に洪定できる.しかしててで問題に なるのは温度分布と伸に関連した形状の決定である。

電流加熱法は，ターミナルの間に摤まれた試験片の一 部分だけに熱を与えて，高温度に加熱するのであるから 必然的に試片の中央から両端に问つて熱の伝播が絶觉ず 生じてぇり，温度勾配は避け難い．勾配を小さくするに は，長い平行部の雨端をターミナルで掝みっその中央の ごく一部分を標点距離として採用すればよい，例えば平 行部の全長を $180 \mathrm{~mm}$ とし，その中央の $30 \mathrm{~mm}$ を禋点 距離とすれば，実测によればその中では温度勾配ははと んど○である.

所がこの様にすると, 引張つた特に標点距離外の部分 の伸びが著しい，高温高速娈形に於いて，標点距竅間の

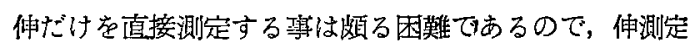
は試験片全長の伸を測定する事となる・その為には殹点

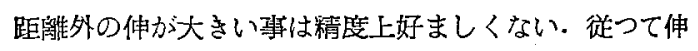
はできるだけ標点距離内に制限したいが，しかし之は温 度分布の均一とは当然相反する条件となる。そてで籍駼 にあたつては両者の折要を計らねばならない。

筆者はこの為に各種の形状について, 温度の分布と, 可張り試験後の伸の分布とを測定して比較し検討した結 果, 最自の形状として Fig.. 2 支決定した.この形状の

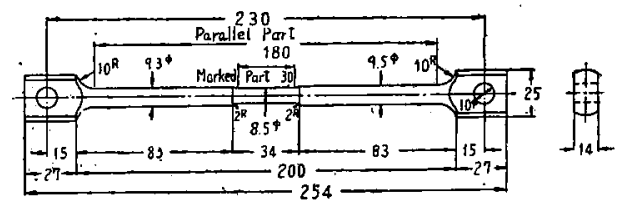

Fig. 2. Shape of Specimen

特徴は, 長い平行部の中央に, 更に直径が $1 \mathrm{~mm}$ 小さい標 点部を設けて，とこに伸を集中させた事である。この上 この標点部 $30 \mathrm{~mm}$ の中 $25 \mathrm{~mm}$ を真の標点距離とした。 ての方法によつて標点距離間の温度分布は中央の温度に 対して常に $\pm 05^{\circ} \mathrm{C}$ 以内に収まり**, 標点距離外の伸は 後に述べる補正により修正できる程度に局幔するととが． できた。

* この $\mathrm{N}_{2}$ の分析住束洋銅板下松工場破究所“行わ机

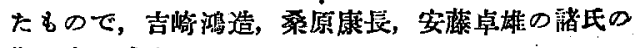
御厚意儿感謝する。

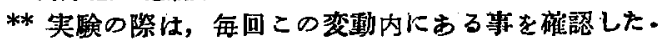




\section{VI. 荷 重 測 定 法}

急激に变化する荷重の測定には種々の方法が考えられ るが，筆者は輪バネの弾性变形を静電容量の变化によつ て榆出する方法をとつた。

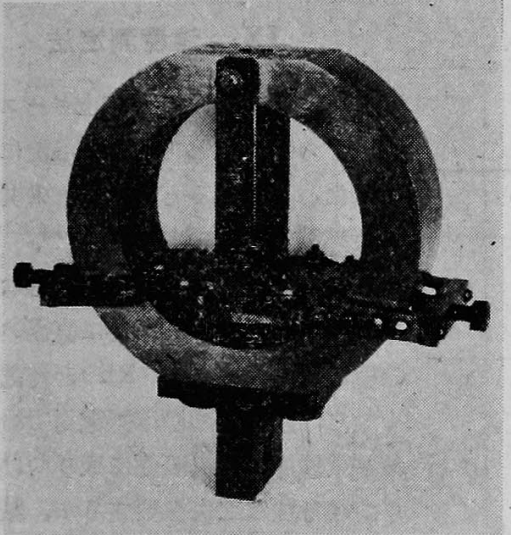

Fig. 3. Steel ring for measuring tension load

Fig. 3 はこの検凷装置である、リングは調質したCrMo 鋼管から削り世したものである.リングの中の下側 に見えるのが 2 枚の梅板であつて，上極板は 2 本の棒に よりリング上端に固定した板に絶緣のための合成樹脂板 を介して取りつけ，下極板はリング下端にねじ込んで固 定してある・リングの両側につけた金具は上極板を左右 に引張つて振動を防止する工夫である*.

この椧装置で最も苦心を要するのは，衝撃荷重によ る振動の発生であつて，その防止には長い間苦心した。 結局リング自体の固有振動の他に，極板支持機構の剛性 を高める事，各種取付部の弛ひをなくする事等が大切で ある・

静電容量の变化は，東慗オートダイン式凯少容量变 化測定装置によつて電流变化に換え之を雪磁オッシェグ ラフのH型振動子に入れて記録した。

実荷重と振動子の振れとの関係は引張り試験機で㭘定 しておくが，測定装置の变動は避け難いから，別に基準 静電容量の变化と振動子の振れとの関俰を実験毎に毎回 求めて，堌门度の变化の影響を除く必要がある.

$100 / \mathrm{s}$ の高速变形の場合は $1 / 1000$ 秒単位の变化の測 定になるが，之は電磁オッシログラフで記録し得る限度 と思われる：

*乙つエ夫は八幡製鉄研究所哑島清三博士の教示に よる.
この為には振動子の糸をやや強く張る等の工夫により 今回の実験程度の速度ならば十分可能である事を確かめ た. 例えば Fig. 4 は常温の鋼の高速引張り試験の結果 を $1200^{\circ} \mathrm{C}$ の場合と比較したものであつて，急速な応力 上年をも十分に記録し得る事を示している.

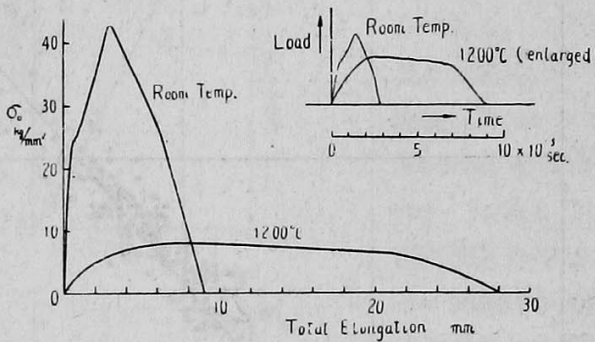

Fig. 4. Stress-strain and load-time curve of mild steel at high speed.

(at room temperature and at $1200^{\circ} \mathrm{C}$ )

\section{VII. 伸 測 定 法}

伸測定法としては試験片の標点距離間の伸だけを直接 測定するのが最も好ましいが，高温高速度の变形では頗 る困難である．恐らく唯一の可能な方法は連続写真をと る事であろう**.

筆者も標点距離の伸を直接測定する然力をしてみたが 満足する結果を得なかつたので，全長の伸を測定し之を 標点間伸に換算する方法をとる事にした.

伸㭘出装置***は Fig. 1 (9)のコイルであつて，その ゆには黄銅棒を介して(10)及び(4)に連結された鉄心があり この鉄心は試験片の伸びた量だけ下降する.インダクタ ソスコイルは2 個からなり，差動的に变化する。この 2 個のコイルと，2 個の固定抵抗，可变抵抗及び固定コン デンサーによつて1つのブリッデを構成してある。最初 2 個のコイルの山央に鉄心を㯰き，可变抵抗を調節して プリッヂの平衡を保つておく、鉄心か䔟動すれば平衡か 破れ，それによつて不平衡電圧が発生する・文を堌门し て電磁オッシログラフに入れて伸の測定とする・ブリ ッヂ電源の周波数は 10,000 サイクルにして，速い变位 そも追随できるようにしてある・鉄心の変位と振動子の 振れの関係は，実験の前後に鉄心を一定量づつ移動させ て検定しておく．此の㭘四装置で得た記録は試験片の全 長の伸であるから，之と標点距離間の伸の関係を求め なければならない，その為に各種の材質，温度及び速

** 大幸氏 ( $^{9}$ は常温の高速引張り 試験でこの方法を行 つた.

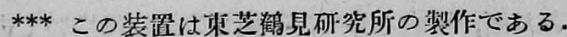




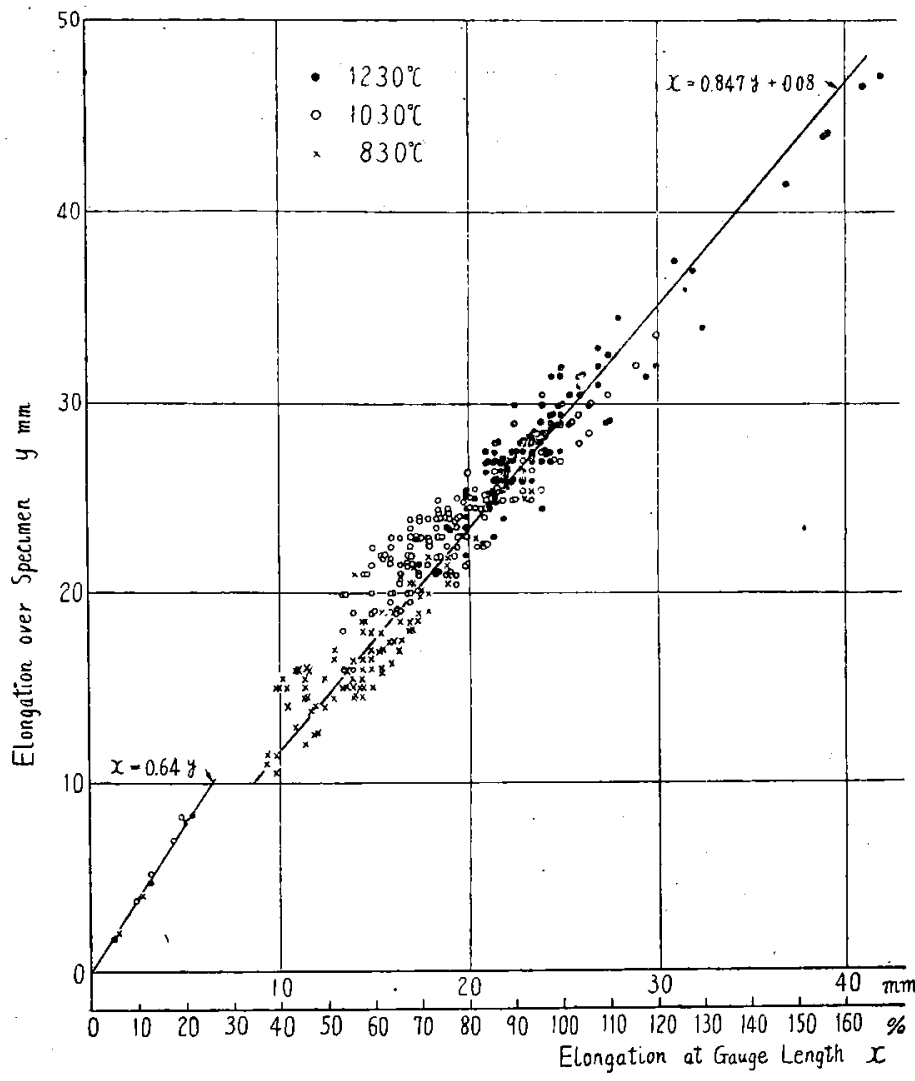

Fig. 5. Corrective diagram to introduce elongation at gauge length from elongation over specimen 度について試験片全長の伸と標点間の伸の関保を集めて ブロットした.その結果は Fig. 5 であつて, 幸いな事 に両者は高度な相関があり，2つの回帰直線で結ぶ事が できる。

第 1 直線は局部収縮開始前，第 2 の直䠌は開始後の 閣係に相当する.試験開始より切断迄の各瞬間の全長伸 の值は，この補正直線を使つて標点距離間の伸に掺算で きる。

\section{VIII. 伸速度の算定}

試験片の伸速度は前節の方法で得た伸一侍間の曲線す 微分すれば得られる. Fig. 6 は低宸素キルド鋼につい て, $1230^{\circ} \mathrm{C}$ と $80^{\circ} \mathrm{C}$ に於ける 3 檑類の速度の記録であ る。四より明らかな如く，速度上身の時間的遅れは止む を得ない. しかし此の点は試験結果の整理の㭙に速度修 正を施可事ができる。

定常状熊てなつた時の伸速庭は，全部の試 路 結果を 検討してみた所，平均として，3 種類の速度について夫
々 $77 / \mathrm{sec}, 7 / \mathrm{sec}$ 及び 0・8/sec である 事がわかつた．この值は，試験片の標点 距離 $25 \mathrm{~mm}$ が伸びる速度を示すもので あつて，今後の試験結果の整理にはすべ てこの值茬用いる.

\section{IX. 温度測定法}

試験片の温度は酸化防止ケースに付け たガラス空を通して，光高温計により浿 定した・この語みと真温度との関係は特

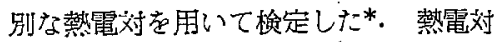
は自身の爇容量が小さくて敏感なもので ある聚を要する方ら，特值径 $0.14 \mathrm{~mm}$ の極めて細いPt-Pt.Rh の熱電対をつ くつた。とを予め標淮熱電対で桧定して おき試驗片の中央裁面に取りつけた。取 りつけ方法は工夫を要するが, 結局, 試 片表面の梁さ $0.5 \mathrm{~mm}$ 程度のマクレなつ くり，そこへ封じ込む事にしたそそして 試験片に規定の電流加熱を行い，光高温 計と熱電対の雨者の境みを比較した。 この結果は Fig. 9 であつて，多数のデ ータはよく1つの直線上にのり，800〜 $1250^{\circ} \mathrm{C}$ の範帮内で, 真温度は光高温計 の読みよりも平均 $25^{\circ} \mathrm{C}$ 高いと見ればよ 认事がかかつた：との值は全輻射能 0.80 に相当し，酸化状態の鍴の輻射能は 0.80 〜 0.87 とい內 れているので，妥当な值と考えられる.

この他に試験片の变形エネルギーも温度上型の原因と

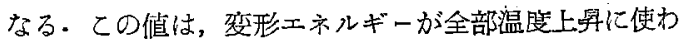
れたとして，色くな鋼種，温度及じ速度について計算す

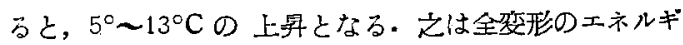
一を換算したものであるから，試験中に発生するのはて の $1 / 2$ と考元，平均して $5^{\circ} \mathrm{C}$ の湿庭補正をする事とし た。

結局 2 つの補正を合せて, 光高温計の芜みに $30^{\circ} \mathrm{C}$ 加 えた值を真温度とする・

\section{X. 試 験 結 果}

以上の方法で試験を行うと，オッシログラムとして， 何重一時間，伸一眭間の曲線が同時に得られるい，之を結 び合せ，伸その他の必要な補正を行えば，応力·雨曲線

* この方法は東大工学部洉義夫教授の御教示による 

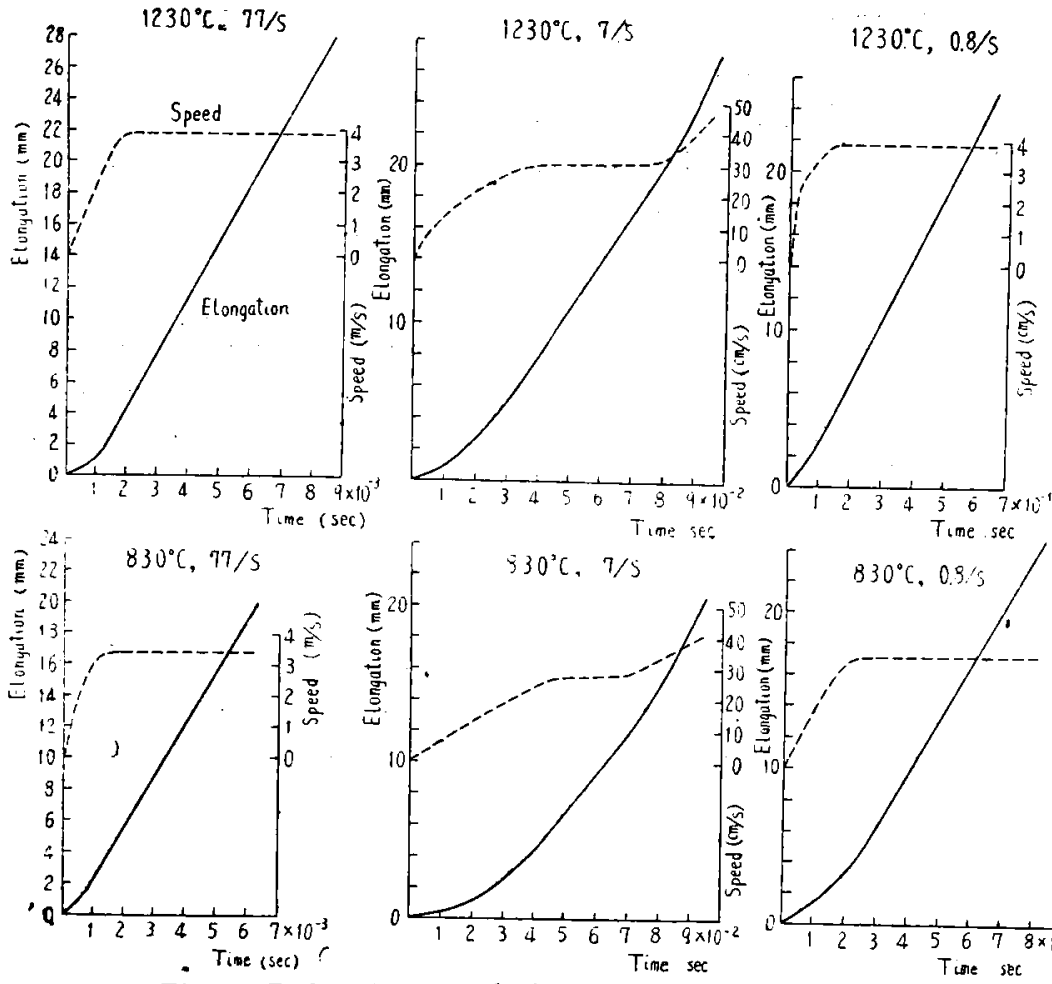

Tine (sec)

Fig. 6. Deforming speed shown in testing records

(low carbon killed steel)

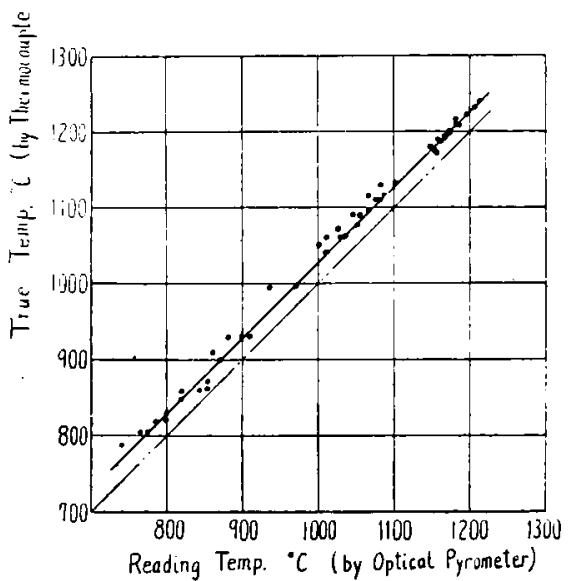

Fig. 7. Relation between true temperature and reading temperature with optical pyrometer.

(Nominal stress-conventional strain curve) を得る事ができる.Fig. 8 はオッジがラムの例とし

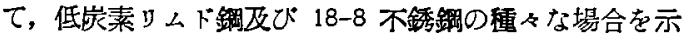
したものである・
XI. 結果の整理

周知の如く，所謂店 力・歪曲線は引張り变 形の概況を知るには有 効であるが, 変形抵抗 の測定値としては不十 分である・ての目的の 為には真応力一対数雨 曲線 (True stressNatural strain curve) が最も良い事が 既に明らかになつてい る・試験片が局部収縮 を生じてから後は，応 力と伸の分布力㳅均一 になる為, 正確な值を 求め得ないが，そ机迄 の間は両者には次の関 係がある。

$$
\begin{aligned}
& \text { 公称它力 } \left.\sigma_{0}=P / a_{0}\right\} \\
& \text { 真店力 } \sigma=P / a\} \\
& \left\{\begin{array}{ll}
\text { 常用歪 } & e=\left(l-l_{0}\right) / l_{0} \\
\text { 然效数霆 } & \varepsilon=\ln \left(l / l_{0}\right)
\end{array}\right\}
\end{aligned}
$$

但し, $P$ : 荷重, $a_{0}$ : 最初の断面積, $a$ : 各橓間の断 面積， $l_{0}$ : 最初の標点距離， $l$ : 各瞬間の標点距離であ る. 位つて $(1 \cdot 1)$ と $(1 \cdot 2)$ 上り次の関保を得る.

$$
\begin{aligned}
& \sigma=\sigma_{0}(1+e) \\
& \varepsilon=\ln (1+e)
\end{aligned}
$$
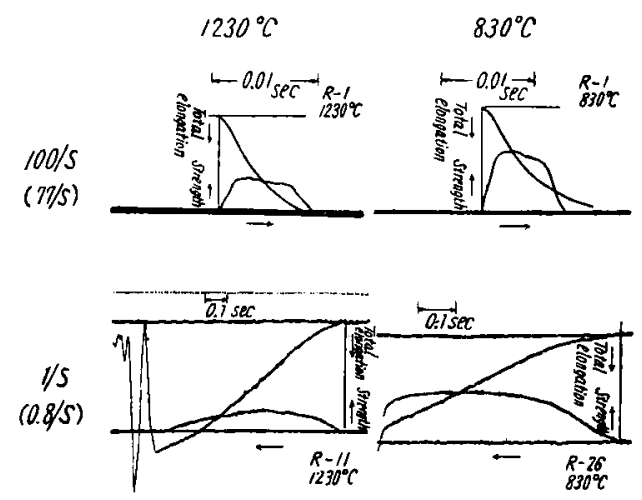

Fig. 8. Examples of oscillogram. 
(1・3）式と (1・4）式によつて，公称応力一歪曲線を真

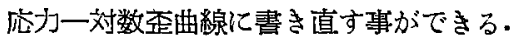

この換算にあたつて管8節で述べた様に，变形初期の 歪の小さい部分には变形速度の修正を施す必要がある. 之には変形抵抗か湾形速度の $m$ 乗に比例するという関 保*を利用する。

$m$ の值は平均 0.15 であるが，各場合仙応じて適当 な值を用いた。

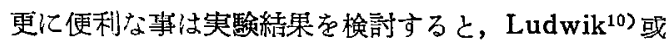
いは Hollomon ${ }^{11)}$ が常温の低速度変形について示して いるのと同様に，真広力と対数昰との間には常に次の簡 単な関係が成立する*。

$$
\sigma=K_{1} \cdot \varepsilon^{n}
$$

或いは

$$
\ln \sigma=K^{\prime}+n \cdot \ln \varepsilon
$$

そこで筆者が真応力一対数歪曲線を求めた方法は，次 の手順による。例として低岸菜りムド鋼の $1230^{\circ} \mathrm{C} 77 / \mathrm{s}$ の場合を Fig. 9 亿示す.

(a) $\sigma_{0}-e$

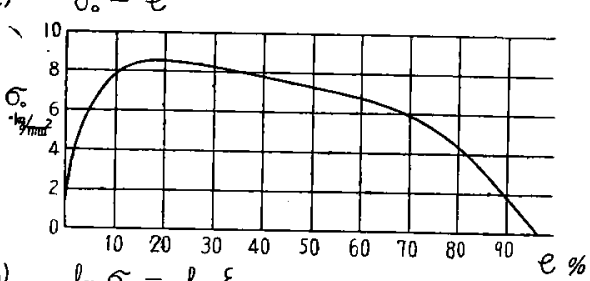

(b)

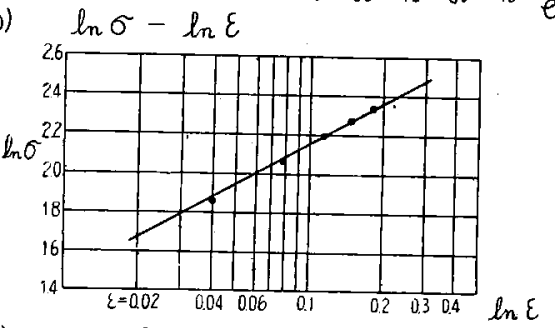

(C)

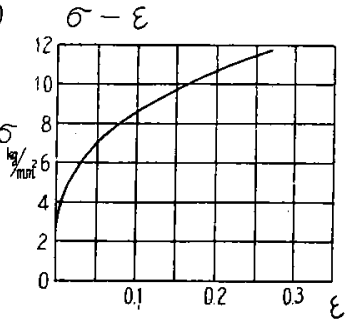

Fig. 9. Procedure to introduce from $\sigma_{0}-e$ curve

（イ）公称店力一丕曲線（Fig.9 a）上り店力一霜の 組台せをいくつか境みとる。

*第2 墛で述てる。

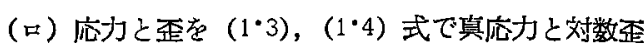
に換算する。

（八）真応力に上記の速度修正を各及について行い， 之と対数正を対数に直してプッットする．その点を連极 て直線を引く. (Fig. 9 b)

（二）上記直線真数江直すと，真尤力一歪曲線とな 3. (Fig. 9 c)

他のすべての鋼種の実医条件の場合も全く同㥞の手順 で真店力一雷曲線を得る事ができる，但しての曲䠌は， 局部収縮発生迄しか得られないから，常用䨜で20〜30\% 迄のデータに限られる。

\section{XII. 高温変形抵抗の意義}

高温に於ける鋼の変形抵抗は，例えぱ Fig. 9(c)でを 明らかな㥞に，垔或いは加工应に著しく左右される．從 つて变形抵抗の定義に泣鋼種，温度，速是の他に加工度 を指定しなければならない。之池島すか溉に强調して いる所であるが，加工度をいくらにとればよいかか閣題 である・

压延等の高温加工を調べると，加工度は ○から 20〜 50\%に反んでおり，蕨密には各瞬間每のすべての加工 度に対する変形抵抗を考光ねばならない，ての意侏では 兴成力一需曲線そのすのか㵊も完全なデータとなるわけ であつて，筆者か河張り試験によつてての曲線を求めた 理由もここにある．然し鋼梗間の比較この他汇は或る加 工度を仮に定めて，その佶の変形抵抗を代表値とするの が便利であるから，籍者は今後その㥞な場合には，常用 霍 20\% を主に用いる事化した。

以上述べたす法による実際の湘定結果は箩 2 報に於い て述べる。

(昭和 29 年 12 月寄槅)

$$
\text { 文藏 }
$$

1) 例元は，前田元三，吉川永一，太田层：各種銅材 の熱間抗張試跧，锞と除，炤和 25 年 4 月 French, H. J. and W. A. Tucker: Iron Age 1923, pp. 193 195

2) Hennecke, H.: Warmstauchversuche mit perlitischen, martenitischen und austenitischen Stähle, St. u. E., 1928 pp. 315 316

3）池島俊堆：高温度に於ける銅の装形抵抗に閶する 破筦，炤和 24 年 5 月，扶桑金属工業報告

4) Nadai, A. and M. Manjoine: High-Speed Tension Test at Elevated Temperatures, (I) Proc. ASTM., 1940, pp. 822 839, (I), (I) J. of Applied Mechanics,..1941, pp 77 
91

5）市原通敏：術擊振 り試臨，第 1 報一第 5 報，日本 栱械学会誌，昭和 7 年 7 月，昭和 10 年 2 月 6 月

6) Siebel, $E$. and $E$. Fangmeier: Versuche über den Formänderungswiderstand und den Formänderungsverlauf beim Warmwalzen, Mitt. K.W.I., 1930, pp. 225 244

7) Pomp. A. and W. Lueg: Walzversuche an kohlenstoff und silizium-legierten Stählen,
Mitt. K.W.I., 1933, pp. 81 97

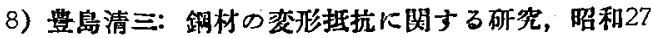
年 1 月，八幡製鉄技術矿究所報告

9）大幸喜三郎：火砲の安全係数について, 火兵学会 誌, 昭和 18 年 1 月, pp. 301 326

10) Ludwik, P.: Element der technologischen Mechanik, 1909

11) Holloman, $J$. H.: Tensile Deformation, Trans. AIME, $1945, \mathrm{p}, 268$

\section{高溫度に於けるスケールの浸透についで}

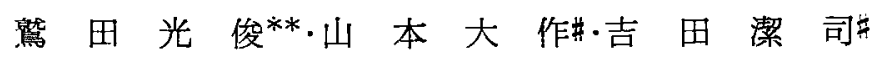

\section{ON SCALE PENETRATION IN STEEL AT HIGH TEMPERATURES}

\section{Mitsutoshi Washida, Daisaku Yamamolo and Kiyoshi Yoshida}

Synopsis:

When the iron and steel are heated in the oxidizing atmosphere at high temperature, the oxidation scale penetrates into matrix right below the surface scale. The authers studied on the phenomena of this penetration under various conditions using a rimmed steel (C $0.08 \%)$.

Heating conditions: temperature $1150^{\circ} \mathrm{C} \sim 1350^{\circ} \mathrm{C}$, atmosphere $\mathrm{O}_{2} 5 \sim 50 \% \mathrm{~N}_{2}$ Bal.

$$
\mathrm{CO}_{2} 5 \sim 50 \% \mathrm{~N}_{2} \text { Bal. }
$$
time $30 \mathrm{mn} \sim 2 \mathrm{~h}$

In order to compare the individual results each other, the depth of penetration and the size of penetrated scale were measured and those results were as follows:

1) The granular scales penetrated in considerable depths even in the atmoshere of only $\mathrm{N}_{2}$ gas, and this penetration depth was nearly the same value gained when it was mixed with gases of $\mathrm{O}_{2}$ or $\mathrm{CO}_{2}$

2) Penetration of scale was greatly affected by the heating temperature:- the higher the temperature, the deeper the depth and the larger the size of the penetrated scales.

3) Heated above $1300^{\circ} \mathrm{C}$, huge scale appears and was remarkable under such conditions as $\mathrm{O}_{2}$ gas was added. Therefore it was evidenced that the penetration of scale took part in the defect of the over-heating.

4) The color of granular penetrated scales were light-bluish-gray and that of the huge scales were composed by both light-and dark-bluish-gray.

5) If the heating condition changed, then the thickness of surface scales increased, and huge penetrating scale was produced even at below $1300^{\circ} \mathrm{C}$.

\section{I. 緒 言}

鋼材を酸化性䨢团気中にて高温度に加熱すると，選択 酸化により非酸化性元素 $(\mathrm{Ni}, \mathrm{Cu}, \mathrm{As})$ がンケール層直 下に濃化し，熱間加工後に久陷として現われることは既 に知られているが, 最近, 亳温加熱によりスケール閻苴下

* 昭和 29 年 10 月本会满演大会にて発表

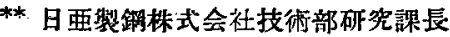

吉同上技衍部䂨究課
の地鉄にスケールか浸透し，その結果熱間加工後に微細 な萑面疪を生しることを認め45) 非酸化性元菜の浱化と 共にスケールの浸透は加熱の影響として重要な問題とな つている. 勿論非酸化性元素の含有量によりスケールの 浸透の程度か左右されるかH.Buchholtz の然験引によれ ば $1250^{\circ} \mathrm{C}$ 近くになると枌筫の差よりも温度の影留が明 らかに認められスケールの浸透は基しくなるといつてい る。㕛田島氏らによれば，蓄面濃化により熱間脆性を起 すとされた估険限界を迸かに下迴つていてもスヶールの 